Article

\title{
High-efficiency oxidative esterification of furfural to methylfuroate with a non-precious metal Co- $\mathrm{N}-\mathrm{C} / \mathrm{MgO}$ catalyst
}

\author{
Na Huo a,b, Hong Ma ${ }^{b}$, Xinhong Wang a, Tianlong Wang a,b, Gang Wang a,b, Ting Wang a,b, \\ Leilei Hou a,b, Jin Gao b,\#, Jie Xu b,* \\ a School of Textile and Material Engineering, Dalian Polytechnic University, Dalian 116034, Liaoning, China \\ ${ }^{\mathrm{b}}$ State Key Laboratory of Catalysis, Dalian Institute of Chemical Physics, Chinese Academy of Sciences, Dalian National Laboratory for Clean Energy, \\ Dalian 116023, Liaoning, China
}

\section{A R T I C L E I N F}

Article history:

Received 7 March 2017

Accepted 15 April 2017

Published 5 July 2017

\section{Keywords:}

Catalysis

Cobalt-nitrogen-doped carbon

Furfural

Methylfuroate

$\mathrm{MgO}$

Oxidative esterification

\begin{abstract}
A B S T R A C T
From both fundamental and practical perspectives, the production of chemicals from biomass resources using high-efficiency non-precious metal catalysts is important. However, many processes require addition of stoichiometric or excess quantities of base, which leads to high energy consumption, leaching problems, and side reactions. In this study, we investigated the high-efficiency oxidative esterification of furfural to methylfuroate by molecular oxygen with a Co-N-C/MgO catalyst. The catalyst was prepared by direct pyrolysis of a cobalt(II) phenanthroline complex on $\mathrm{MgO}$ at $800{ }^{\circ} \mathrm{C}$ under $\mathrm{N}_{2}$ atmosphere. From furfural, 93.0\% conversion and 98.5\% selectivity toward methylfuroate were achieved under $0.5 \mathrm{MPa} \mathrm{O}_{2}$ with reaction at $100{ }^{\circ} \mathrm{C}$ for $12 \mathrm{~h}$ without a basic additive. The conversion and selectivity were much higher than those obtained with cobalt catalysts produced by pyrolysis of a cobalt(II) phenanthroline complex on activated carbon or typical basic supports, including $\mathrm{NaX}, \mathrm{NaY}$, and $\mathrm{CaO}$. X-ray photoelectron spectroscopy, X-ray diffraction, transmission electron microscopy, and experimental results revealed that the high efficiency of Co-N-C/MgO for production of methylfuroate was closely related to the cobalt-nitrogen-doped carbon species and its catalytic ability in hydrogen abstraction. In contrast, Co- $\mathrm{N}-\mathrm{C}(\mathrm{HCl})$ that synthesized by removing $\mathrm{MgO}$ with $\mathrm{HCl}$ from $\mathrm{Co}-\mathrm{N}-\mathrm{C} / \mathrm{MgO}$, as the catalyst produced mainly an acetal as a condensation product, and chloride ions had a negative effect on the oxidative esterification. Although the catalytic performance of the cobalt-nitrogen-doped carbon species was greatly affected by $\mathrm{HCl}$ treatment, it could be recovered to a great extent by addition of MgO. Moreover, changes in the oxygen pressure hardly affected the oxidative esterification of furfural with $\mathrm{Co}-\mathrm{N}-\mathrm{C} / \mathrm{MgO}$. This study not only provides an effective approach to prepare methylfuroate, but also for designing high-performance non-precious metal catalysts for the oxidative esterification of biomass-derived compounds.
\end{abstract}

(C) 2017, Dalian Institute of Chemical Physics, Chinese Academy of Sciences. Published by Elsevier B.V. All rights reserved.

\section{Introduction}

The non-precious metal approach for production of chemi- cals from biomass resources is attracting immense research interest globally and is very important from the perspectives of green chemistry and sustainable development [1-6]. For

\footnotetext{
* Corresponding author. Tel/Fax: +86-411-84379245; E-mail: xujie@dicp.ac.cn

\# Corresponding author. Tel/Fax: +86-411-84379245; E-mail: gaojin@dicp.ac.cn

This work was supported by the National Natural Science Foundation of China $(21233008,21643013,21690084)$, the Strategic Priority Research Program of the Chinese Academy of Sciences (XDB17020300), and the Youth Innovation Promotion Association CAS (2013121). DOI: 10.1016/S1872-2067(17)62841-9 | http://www.sciencedirect.com/science/journal/18722067 | Chin. J. Catal., Vol. 38, No. 7, July 2017
} 
large-scale biomass conversions, precious metal catalysts and basic additives are generally used to achieve high performance. A typical case is the oxidative esterification of furfural, which is derived from lignocellulosic biomass and recognized as a promising renewable resource [7-11], to produce methylfuroate. It is an attractive route because of the applications of methylfuroate as an anti-explosive additive in petrol and an anti-tumor drug. In most cases, homogeneous bases are added to promote the reaction and facilitate the abstraction of active hydrogen. For example, $\mathrm{Au} / \mathrm{Fe}_{x} \mathrm{O}_{y}$-hydroxyapatite catalyst affords a $92 \%$ yield of methylfuroate with addition of $\mathrm{K}_{2} \mathrm{CO}_{3}$ after reaction at $140{ }^{\circ} \mathrm{C}$ for $4 \mathrm{~h}$ [12]. Christensen et al. [11] reported that addition of $\mathrm{CH}_{3} \mathrm{ONa}$ remarkably improved the catalytic performance of $\mathrm{Au} / \mathrm{TiO}_{2}$ in the oxidative esterification of furfural. Recently, $\mathrm{Co}_{x} \mathrm{O}_{y}$-N@C showed high potential in catalysis, and gave a 95\% yield of methylfuroate from furfural and methanol with addition of $\mathrm{K}_{2} \mathrm{CO}_{3}$ [13]. However, base additives lead to high energy consumption, leaching problems, and side reactions. In future, it is necessary to develop an inexpensive and environmentally friendly catalyst that provides efficient oxidative esterification of furfural without the requirement for a basic additive.

Metal-containing $\mathrm{N}$-doped carbon catalysts can be used as an alternative to precious metal catalysts, and are inexpensive and show unique properties in electrocatalysis [14-16] and organic reactions [17-20]. To date, various cobalt-nitrogendoped carbon catalysts have been synthesized by pyrolysis of nitrogen-rich metal complexes or mixtures of metal salts and $\mathrm{N}$-containing ligands on supports under an inert atmosphere. Research has focused on the structures and factors influencing the catalytic activity. There is evidence that a single Co atom bonded to $\mathrm{N}$ atoms within graphitic sheets can act as an active center in aerobic oxidative cross-coupling and hydrogenative coupling reactions [21,22]. Basic additives, such as LiOH or $\mathrm{NaOH}$, are indispensable for Co- $\mathrm{N}-\mathrm{C}$ catalysts in these reactions, and it is not known if Co-N-C catalysts can achieve high efficiency without the assistance of basic additives.

Previous studies performed in our laboratory showed that the basic support $\mathrm{Mg}(\mathrm{OH})_{2}$ remarkably increased the performance of gold catalyst in oxidative conversions [23]. Further research indicated that pyridinic $\mathrm{N}$-doped carbon species might behave as Lewis bases and greatly promoted the catalysis of $\mathrm{CoO}_{x}-\mathrm{N} / \mathrm{C}$ to achieve high efficiency for the oxidative esterification of diformylfuran in a neutral medium [24]. These findings suggested that cobalt-nitrogen-doped carbon supported on basic carrier could realize high efficiency oxidation of furfural without the requirement for a basic additive. In the present study, a Co-N-C/MgO catalyst was synthesized and used for production of high yields of methylfuroate under mild conditions without any basic additives. This method could be used for the development of high-performance non-precious metal catalysts for oxidative esterification conversions of biomass and biomass-derived compounds.

\section{Experimental}

\subsection{Materials}

All reagents and chemicals used were of analytical grade unless otherwise specified. Furfural, MgO, ethanol, activated carbon, and 1,10-phenanthroline were obtained from Aladdin Chemistry Co. Ltd. (Shanghai, China). Methanol was obtained from Kermel Chemical Reagent Development Center (Tianjin, China). Cobalt acetate tetrahydrate was from Sinopharm Chemical Reagent Co. Ltd. NaX and $\mathrm{NaY}$ were from Nanhua Catalyst Co. Ltd (Tianjin, China). CaO was from Damao Chemical Reagent Factory (Tianjin, China).

\subsection{Catalyst preparation}

The Co-N-C/MgO catalyst was synthesized according to a reported method with some modifications [18]. 1,10Phenanthroline (182 mg, $1.0 \mathrm{mmol}$ ) and cobalt acetate tetrahydrate (125.8 $\mathrm{mg}, 0.5 \mathrm{mmol}$ ) were dissolved in $50 \mathrm{~mL}$ of ethanol and stirred for $30 \mathrm{~min}$ at room temperature. Then, $692.2 \mathrm{mg}$ of $\mathrm{MgO}$ was added to the solution, and the mixture was stirred for $4 \mathrm{~h}$ at $60{ }^{\circ} \mathrm{C}$. The ethanol was removed under vacuum and the mixture was cooled to room temperature. The sample was then dried at $80^{\circ} \mathrm{C}$ for $12 \mathrm{~h}$. Then, the sample was placed in an oven, which was heated to $800{ }^{\circ} \mathrm{C}$ at $25^{\circ} \mathrm{C} \mathrm{min}-1$ and maintained at this temperature for $2 \mathrm{~h}$ under a nitrogen atmosphere. For comparison, cobalt-based catalysts were prepared by a similar method using activated carbon and typical basic supports $(\mathrm{NaX}, \mathrm{NaY}$, and $\mathrm{CaO})$. The resulting samples were denoted as $\mathrm{CoO}_{X}-\mathrm{N} / \mathrm{C}, \mathrm{CoNC} / \mathrm{NaX}, \mathrm{CoNC} / \mathrm{NaY}$, and $\mathrm{CoNC} / \mathrm{CaO}$.

\subsection{Catalyst characterization}

The samples were analyzed by X-ray powder diffraction (XRD) on a Rigaku D/Max 2500/PC powder diffractometer with $\mathrm{Cu} K_{\alpha}$ radiation $(\lambda=0.15418 \mathrm{~nm})$ at $40 \mathrm{kV}$ and $200 \mathrm{~mA}$ at a scanning rate of $5^{\circ} \mathrm{min}^{-1}$. Transmission electron microscopy (TEM) images were obtained using a JEOL JEM-2000EX electron microscope with samples deposited on a carbon polymer supported copper grid. X-ray photoelectron spectroscopy (XPS) measurements were performed on a Thermo ESCALAB 250Xi using a Mg $K_{\alpha}(1253.6 \mathrm{eV})$ radiation source and a chamber pressure lower than $5 \times 10^{-8} \mathrm{~Pa}$. Inductively coupled plasma optical emission spectrometry (ICP-OES) using a Perkin Elmer ICP-OES 7300DV was used to determine the cobalt content. A carbon/sulfur analyzer (EMIA-8100, HORIBA) and oxygen/nitrogen/hydrogen analyzer (EMGA-930, HORIBA) were used to determine the carbon and nitrogen contents, respectively.

\subsection{Oxidative esterification of furfural}

Oxidative esterification of furfural was performed in a 10-mL Teflon lined stainless steel autoclave equipped with a magnetic stirrer, a pressure gauge, and automatic temperature control apparatus. Typically, $0.5 \mathrm{mmol}$ of furfural, $80 \mathrm{mg}$ of Co-N-C/MgO (3.9\% mass fraction, $0.05 \mathrm{mmol}$ of $\mathrm{Co}$ ), and $5 \mathrm{~mL}$ of methanol were loaded into the autoclave. The autoclave was purged with oxygen and then pressurized to the required value. 
During the reaction, the pressure was maintained by supplying oxygen. After the reaction was completed, the autoclave was cooled to room temperature. The liquid reaction mixture was analyzed on an Agilent gas chromatograph (GC7890D) equipped with a flame ionization detector (FID) and Agilent GC/MS 6890-5973. The conversion and selectivity toward methylfuroate were evaluated by the internal standard method using $n$-dodecane as the internal standard.

\section{Results and discussion}

\subsection{Catalyst characterization}

First, the Co-N-C/MgO catalyst was analyzed by XRD in the range $5^{\circ}-80^{\circ}$. The $\mathrm{Co}-\mathrm{N}-\mathrm{C} / \mathrm{MgO}$ only displayed diffraction peaks for MgO (Fig. 1(e)), and no cobalt nanoparticles were observed on the surface of the MgO in the TEM image (Fig. 1(b)). After acid treatment and microwave digestion, the Co-N-C/MgO was analyzed by ICP-OES. The results confirmed the formation of cobalt, nitrogen, and carbon after pyrolysis under $\mathrm{N}_{2}$. The cobalt was highly dispersed on the catalyst surface, and cobalt-nitrogen-doped carbon species formed. To verify this, the Co-N-C/MgO was treated with $2 \mathrm{~mol} \mathrm{~L}^{-1} \mathrm{HCl}$ to remove $\mathrm{MgO}$, which was confirmed by the disappearance of its characteristic peaks in the XRD pattern (Fig. 1(f)). Additionally, a diffraction peak appeared at $26^{\circ}$, indicating that the carbon formed (carbon mass fraction $=71.8 \%$ by ICP). In contrast to
Co-N-C/MgO, the TEM image (Fig. 1(c)) of self-supported Co-N-C(HCl) showed obvious MgO-shaped cavities, which would have been occupied by $\mathrm{MgO}$ before the acid treatment. Moreover, the ICP-OES results showed that the Co-N-C(HCl) contained cobalt and nitrogen. These observations were consistent with previous reports that the moderate interaction of $\mathrm{MgO}$ with Co species may be beneficial for generation of cobalt-nitrogen-doped carbon species by pyrolysis of a cobalt(II) phenanthroline complex on MgO [22].

XPS was used to characterize the $\mathrm{N}$ and Co. The $\mathrm{N} 1 s$ spectrum of Co-N-C/MgO displayed three peaks at 399.0, 400.8, and 402.0-403.2 eV, which could be assigned to pyridinic $\mathrm{N}$ bonded to cobalt, graphitic $\mathrm{N}$, and pyridine $\mathrm{N}$-oxide, respectively (Fig. 2) [21,25]. Meanwhile, in agreement with the $\mathrm{N} 1 s$ spectrum and XRD pattern, the binding energy of the Co $2 p_{3 / 2}$ peak at $780.5 \mathrm{eV}$ and its satellite peak corresponded to $\mathrm{Co}(\mathrm{II})$, which may be coordinated with $\mathrm{N}$ atoms in the carbon species [26,27]. These results revealed that cobalt-nitrogendoped carbon species and carbon were formed by pyrolysis of a cobalt(II) phenanthroline complex on $\mathrm{MgO}$ at $800{ }^{\circ} \mathrm{C}$ under a $\mathrm{N}_{2}$ atmosphere, which agrees with previous research $[15,21,22,28]$.

\subsection{Catalytic performance}

The catalytic performance of $\mathrm{Co}-\mathrm{N}-\mathrm{C} / \mathrm{MgO}, \mathrm{CoO}_{x}-\mathrm{N} / \mathrm{C}$, $\mathrm{CoNC} / \mathrm{NaX}$, CoNC/NaY, and $\mathrm{CoNC} / \mathrm{CaO}$ was compared.
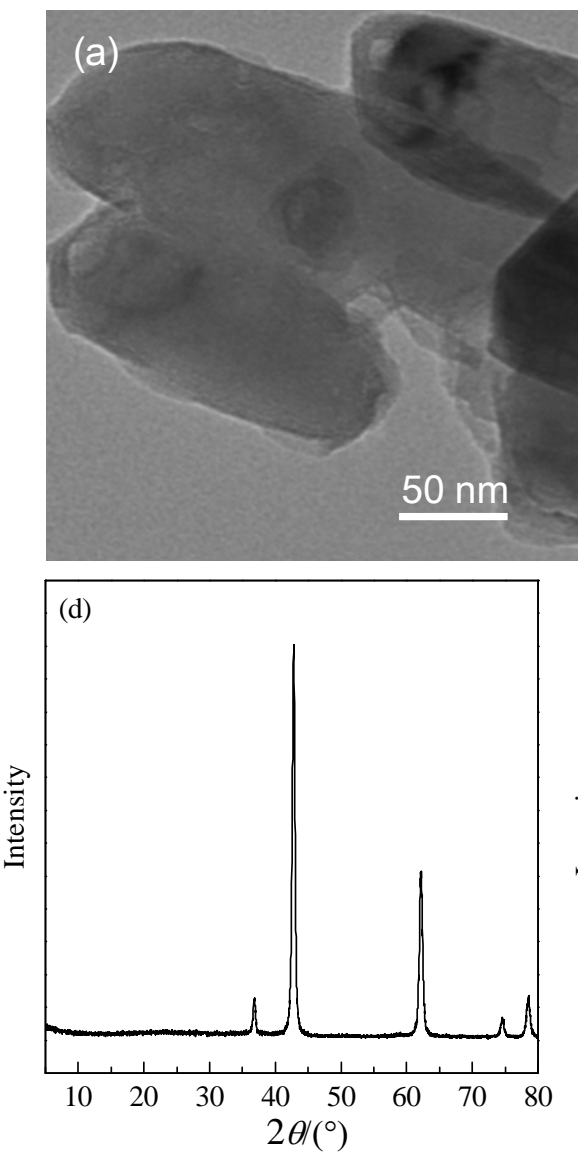
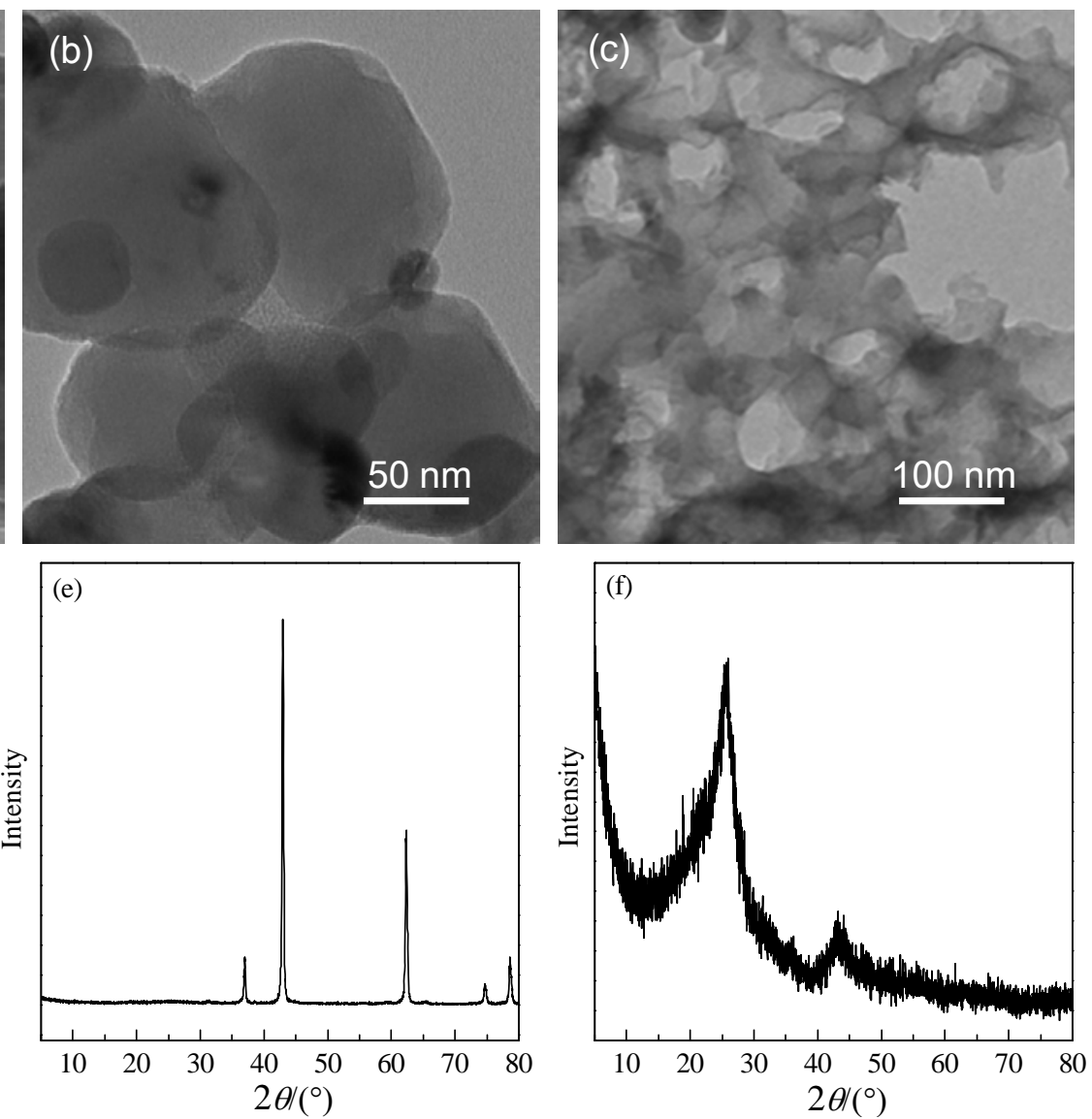

Fig. 1. TEM images of $\mathrm{MgO}(\mathrm{a}), \mathrm{Co}-\mathrm{N}-\mathrm{C} / \mathrm{MgO}(\mathrm{b})$, and $\mathrm{Co}-\mathrm{N}-\mathrm{C}(\mathrm{HCl})(\mathrm{c})$; $\mathrm{XRD}$ patterns of $\mathrm{MgO}$ (d), $\mathrm{Co}-\mathrm{N}-\mathrm{C} / \mathrm{MgO}(\mathrm{e})$, and Co-N-C(HCl) (f). 

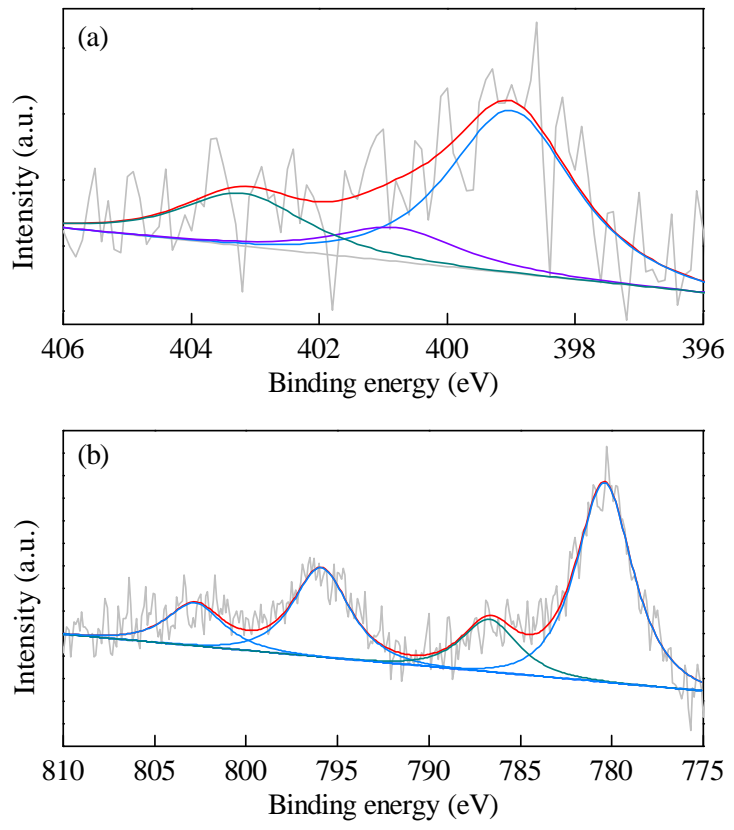

Fig. 2. XPS spectra of the $\mathrm{N} 1 s$ (a) and Co $2 p_{3 / 2}$ (b) electron regions of $\mathrm{Co}-\mathrm{N}-\mathrm{C} / \mathrm{MgO}$.

Exploratory experiments were performed in methanol in a 10-mL autoclave reactor (Fig. 3). Co-N-C/MgO exhibited excellent performance in the oxidative esterification of furfural without a basic additive, where it gave $89.3 \%$ conversion of furfural to methylfuroate with $90.1 \%$ selectivity at $100{ }^{\circ} \mathrm{C}$ for 6 $\mathrm{h}$. When the reaction time was increased to $12 \mathrm{~h}$, a satisfactory result (93.0\% conversion with 98.5\% selectivity toward methylfuroate) was obtained. In previous studies, cobalt oxide-nitrogen/catalyst $\left(\mathrm{CoO}_{x}-\mathrm{N} / \mathrm{C}\right)$ gave a good yield for methylfuroate produced by oxidative esterification of furfural with $\mathrm{K}_{2} \mathrm{CO}_{3}$ as an additive $[13,26]$. Here, $\mathrm{CoO}_{x}-\mathrm{N} / \mathrm{C}$ only gave a

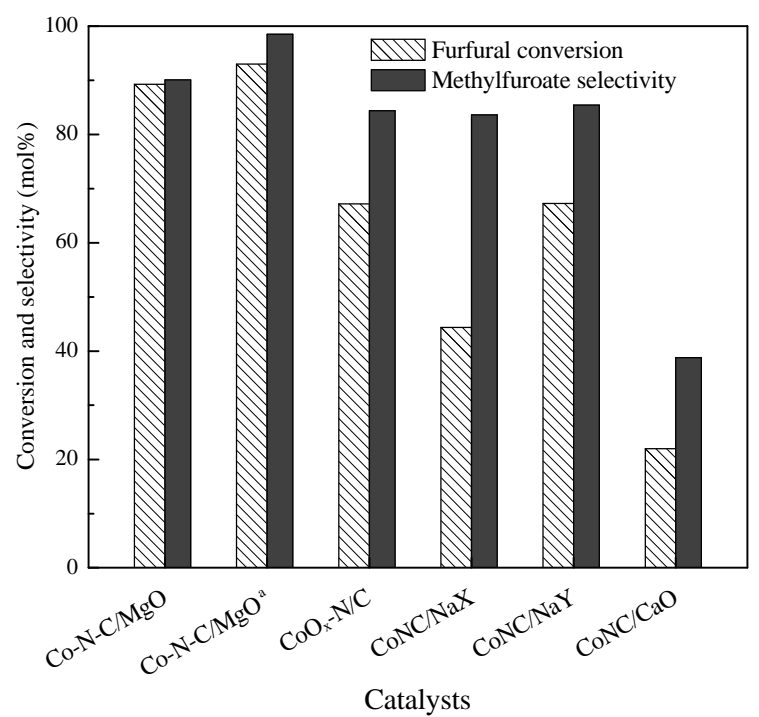

Fig. 3. Catalytic performance of various Co-based catalysts in the oxidative esterification of furfural. Reaction conditions: $0.5 \mathrm{mmol}$ furfural, 80 $\mathrm{mg}$ catalyst, $5 \mathrm{~mL}$ methanol, $100^{\circ} \mathrm{C}, 0.5 \mathrm{MPa} \mathrm{O}_{2}$, and $6 \mathrm{~h}$ or ${ }^{\mathrm{a}} 12 \mathrm{~h}$.
$67.2 \%$ conversion of furfural and $84.4 \%$ selectivity toward methylfuroate without addition of a base. By contrast, the Co-based catalysts with the typical basic zeolites $\mathrm{NaX}$ and $\mathrm{NaY}$ as supports exhibited moderate catalytic activity with $83.6 \%$ and $85.4 \%$ selectivity toward methylfuroate, respectively. CoNC/CaO only achieved $22.0 \%$ conversion and $38.8 \%$ selectivity toward methylfuroate. The choice of support obviously affected both the catalytic activity and selectivity. As demonstrated by XRD, TEM, XPS, and previous reports, the use of $\mathrm{MgO}$ as a support gave good distribution and formation of cobalt-nitrogen-doped carbon species, which may be closely related to the remarkable catalytic activity of Co-N-C/MgO.

Considering that hydrogen abstraction is a key step in the oxidative esterification of an aldehyde with an alcohol, we compared the catalytic performance of $\mathrm{Co}-\mathrm{N}-\mathrm{C} / \mathrm{MgO}$ with other Co-based catalysts in the dehydrogenative esterification of furfural with methanol under $\mathrm{N}_{2}$ (Table 1). The choice of support was critical for the selectivity to the dehydrogenative esterification product, which was consistent with the results for oxidative esterification. As expected, in the presence of $\mathrm{Co}-\mathrm{N}-\mathrm{C} / \mathrm{MgO}$, the reaction of furfural with methanol at $100{ }^{\circ} \mathrm{C}$ mainly converted the aldehyde into ester. $\mathrm{Co}-\mathrm{N}-\mathrm{C} / \mathrm{MgO}$ exhibited the highest selectivity toward methylfuroate, whereas $\mathrm{CoO}_{x}-\mathrm{N} / \mathrm{C}$, $\mathrm{CoNC} / \mathrm{NaX}, \mathrm{CoNC} / \mathrm{NaY}$, and CoNC/CaO were not efficient for the generation of methylfuroate. These results imply that the excellent performance of $\mathrm{Co}-\mathrm{N}-\mathrm{C} / \mathrm{MgO}$ could be attributed to its good catalytic ability in hydrogen abstraction.

To further investigate the catalytic performance of the cobalt-nitrogen-carbon species, $\mathrm{Co}-\mathrm{N}-\mathrm{C}(\mathrm{HCl})(0.05 \mathrm{mmol}$ of $\mathrm{Co})$ was synthesized by removing $\mathrm{MgO}$ with $\mathrm{HCl}$, and used as a catalyst in the oxidative esterification of furfural in methanol under $0.5 \mathrm{MPa} \mathrm{O}_{2}$ at $100{ }^{\circ} \mathrm{C}$ for $5 \mathrm{~h}$. Interestingly, in the absence of $\mathrm{MgO}$, the majority of furfural was converted to the acetal (2-(dimethoxymethyl)furan, $81.0 \%$ conversion), and no methylfuroate was detected by GC analysis. To obtain more information, $\mathrm{MgO}$ was introduced (molar ratio of $\mathrm{MgO} / \mathrm{Co}=$ $34.8)$ to the $\mathrm{Co}-\mathrm{N}-\mathrm{C}(\mathrm{HCl})$. The GC/MS chromatograms obtained before and after addition of $\mathrm{MgO}$ were distinct (Fig. 4). MgO dramatically increased the selectivity toward the ester, with the selectivity toward methylfuroate increasing from not detected to $84.4 \%$ (Table 2, entry 2). This showed the catalytic performance of the cobalt-nitrogen-doped carbon species was greatly affected by $\mathrm{HCl}$ treatment, but could be recovered to a great extent by addition of $\mathrm{MgO}$. The condensation of furfural with methanol to acetal and the oxidative esterification of furfural to methylfuroate are competitive pathways, with the

Table 1

Dehydrogenative esterification of furfural with methanol.

\begin{tabular}{lccc}
\hline Entry & Catalyst & Conversion $(\mathrm{mol} \%)$ & Selectivity ${ }^{\mathrm{a}}(\mathrm{mol} \%)$ \\
\hline 1 & $\mathrm{Co}-\mathrm{N}-\mathrm{C} / \mathrm{MgO}$ & 11.2 & 81.2 \\
2 & $\mathrm{CoO}{ }_{x} \mathrm{~N} / \mathrm{C}$ & 16.6 & 43.7 \\
3 & $\mathrm{CoNC} / \mathrm{NaX}$ & 12.9 & 55.8 \\
4 & $\mathrm{CoNC} / \mathrm{NaY}$ & 18.4 & 43.0 \\
5 & $\mathrm{CoNC} / \mathrm{CaO}$ & 12.3 & 35.7 \\
\hline
\end{tabular}

Reaction conditions: $0.5 \mathrm{mmol}$ furfural, $80 \mathrm{mg}$ catalyst, $5 \mathrm{~mL}$ methanol, $10{ }^{\circ} \mathrm{C}, 0.1 \mathrm{MPa} \mathrm{N} \mathrm{N}_{2}$ (initial pressure before heating), and $12 \mathrm{~h}$. ${ }^{a}$ Selectivity toward methylfuroate. 

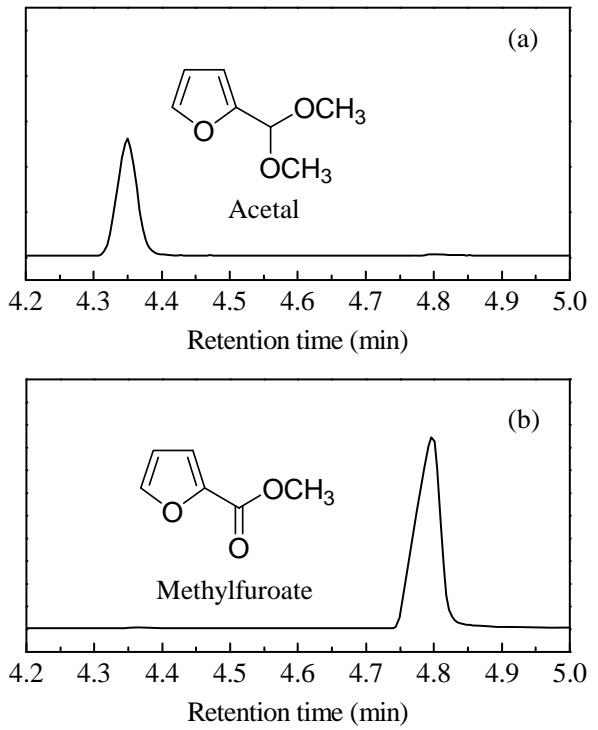

Fig. 4. Typical GC/MS chromatograms for (a) condensation and (b) oxidative esterification of furfural with methanol. Reaction conditions: $0.5 \mathrm{mmol}$ furfural, $5 \mathrm{~mL}$ methanol, $100{ }^{\circ} \mathrm{C}, 0.5 \mathrm{MPa} \mathrm{O}_{2}, 5 \mathrm{~h}$; (a) $58.9 \mathrm{mg}$ Co-N-C(HCl), (b) $58.9 \mathrm{mg} \mathrm{Co-N-C(HCl)} \mathrm{and} 70 \mathrm{mg} \mathrm{MgO.}$

dominant process determining the main product. These differences indicated that the - $\mathrm{CHO}$ groups were mainly converted via the competing condensation pathway with Co- $\mathrm{N}-\mathrm{C}(\mathrm{HCl})$, or via the oxidative esterification pathway with $\mathrm{Co}-\mathrm{N}-\mathrm{C}(\mathrm{HCl})$ and $\mathrm{MgO}$. Other research has shown that specific anions, including $\mathrm{Cl}^{-}$, greatly affect the catalyst performance of $\mathrm{M}-\mathrm{N}-\mathrm{C}$ catalyst because they might coordinate with the active metal center [29]. In our case, although the $\mathrm{MgO}$ could be removed from the $\mathrm{Co}-\mathrm{N}-\mathrm{C} / \mathrm{MgO}$ by washing with $\mathrm{HCl}$, residual $\mathrm{Cl}^{-}$may affect the metal center and lead to an obvious loss of catalytic activity for the oxidative esterification.

Two experiments were carried out to confirm the negative role of $\mathrm{Cl}^{-}$. When $\mathrm{NaCl}(0.5 \mathrm{mmol})$ was introduced to the reaction with the $\mathrm{Co}-\mathrm{N}-\mathrm{C} / \mathrm{MgO}$ catalyst, the conversion decreased from $93.0 \%$ to $56.3 \%$ and the selectivity toward methylfuroate decreased slightly (Table 2, entry 3). If $\mathrm{Co}-\mathrm{N}-\mathrm{C} / \mathrm{MgO}$ was pretreated with $\mathrm{NaCl}$ solution, thoroughly washed with water, and then calcined at $800{ }^{\circ} \mathrm{C}$, both the conversion and selectivity decreased obviously (Table 2, entry 4). These changes confirmed that $\mathrm{Cl}^{-}$ions had a negative effect on the oxidative esterification reaction. Therefore, we believe

Table 2

Catalytic performance of various Co-based catalysts in the oxidative esterification of furfural.

\begin{tabular}{lccccc}
\hline Entry & Catalyst & $\begin{array}{c}\text { Co content } \\
(\mathrm{wt} \%)\end{array}$ & $\begin{array}{c}\text { Addi- } \\
\text { tive }\end{array}$ & $\begin{array}{c}\text { Conversion Selectivity } \\
\text { (mol\%) }\end{array}$ & $\begin{array}{c}\text { (mol\%) } \\
\text { (mol\% }\end{array}$ \\
\hline 1 & $\mathrm{Co}-\mathrm{N}-\mathrm{C}(\mathrm{HCl})$ & 5.3 & - & 81.0 & n.d. \\
2 & $\mathrm{Co}-\mathrm{N}-\mathrm{C}(\mathrm{HCl})$ & 5.3 & $\mathrm{MgO}$ & 90.0 & 84.4 \\
3 & $\mathrm{Co}-\mathrm{N}-\mathrm{C} / \mathrm{MgO}{ }^{\text {b }}$ & 3.9 & $\mathrm{NaCl}$ & 56.3 & 88.4 \\
4 & $\mathrm{Co}-\mathrm{N}-\mathrm{C} / \mathrm{MgO}(\mathrm{NaCl})^{\text {b }}$ & - & - & 64.4 & 67.5 \\
5 & $\mathrm{CoO}_{x}-\mathrm{N} / \mathrm{C} \mathrm{c}^{\mathrm{c}}$ & 3.9 & $\mathrm{~K}_{2} \mathrm{CO}_{3}$ & 92.6 & 95.0 \\
6 & $\mathrm{Co}-\mathrm{N}-\mathrm{C} / \mathrm{MgO}{ }^{\text {c }}$ & 3.9 & $\mathrm{~K}_{2} \mathrm{CO}_{3}$ & 99.6 & 95.2 \\
\hline
\end{tabular}

Reaction conditions: $0.5 \mathrm{mmol}$ furfural, Co-based catalyst $(0.05 \mathrm{mmol}$ Co), $5 \mathrm{~mL}$ methanol, $100{ }^{\circ} \mathrm{C}, 0.5 \mathrm{MPa} \mathrm{O}_{2}, 5 \mathrm{~h}$, b $12 \mathrm{~h}^{\text {or }}{ }^{\mathrm{c}} 6 \mathrm{~h}$.

a Selectivity to methylfuroate. that using $\mathrm{MgO}$ as a support or additive allows for high catalytic efficiency of the cobalt-nitrogen-doped carbon catalyst and greatly reduces the negative effects of $\mathrm{Cl}^{-}$. In addition, preliminary studies indicated that the use of basic additives such as $\mathrm{K}_{2} \mathrm{CO}_{3}$ could increase the catalytic activity and selectivity in oxidation and oxidative esterification reactions by promoting the elimination of active hydrogen. Thus, $\mathrm{Co}-\mathrm{N}-\mathrm{C} / \mathrm{MgO}$ was compared with the representative Co-based catalyst $\mathrm{CoO}_{x}-\mathrm{N} / \mathrm{C}$ in the oxidative esterification of furfural in methanol with the addition of $0.1 \mathrm{mmol}$ of $\mathrm{K}_{2} \mathrm{CO}_{3}$. Both catalysts achieved excellent results. Using $\mathrm{CoO}_{x}-\mathrm{N} / \mathrm{C}$, the conversion increased from $67.2 \%$ to $92.6 \%$ and the selectivity toward methylfuroate increased from $84.4 \%$ to $95.0 \%$. Meanwhile, Co-N-C/MgO gave $99.6 \%$ conversion with $95.2 \%$ selectivity toward methylfuroate. Therefore, the effect of $\mathrm{MgO}$ is similar to that of $\mathrm{K}_{2} \mathrm{CO}_{3}$, which implies that $\mathrm{MgO}$ may play a similar role to a base like $\mathrm{K}_{2} \mathrm{CO}_{3}$ in this reaction.

Next, the reaction conditions for the oxidative esterification of furfural with $\mathrm{Co}-\mathrm{N}-\mathrm{C} / \mathrm{MgO}$ catalyst were optimized. The catalytic performance of $\mathrm{Co}-\mathrm{N}-\mathrm{C} / \mathrm{MgO}$ was investigated at $100{ }^{\circ} \mathrm{C}$ for $6 \mathrm{~h}$ with oxygen pressures of $0.3,0.5,0.7$, and $1.0 \mathrm{MPa}$ (Table 3, entries 1-3 and Fig. 3). The oxygen pressure had a negligible effect on the oxidative esterification of furfural with $\mathrm{Co}-\mathrm{N}-\mathrm{C} / \mathrm{MgO}$ in this pressure range. Considering the conversion of furfural may reach or be close to maximum values at $6 \mathrm{~h}$, we shortened the reaction time to $1.5 \mathrm{~h}$ to further investigate the effect of the oxygen pressure. As expected, even at moderate conversion, there was also no apparent change in the conversion or selectivity toward methylfuroate with changes in the oxygen pressure. Additionally, the influence of temperature was examined at $60,80,100$, and $120^{\circ} \mathrm{C}$ (Table 3 , entries 8-10 and Fig. 3). The conversion of furfural gradually increased as the reaction temperature increased, and $100{ }^{\circ} \mathrm{C}$ and $120{ }^{\circ} \mathrm{C}$ were the optimum temperatures for this reaction.

Recycling of the Co- $\mathrm{N}-\mathrm{C} / \mathrm{MgO}$ catalyst was investigated by evaluating the catalytic activity in repeat use for the oxidation esterification of furfural at $100{ }^{\circ} \mathrm{C}$ under $0.5 \mathrm{MPa} \mathrm{O}_{2}$. The $\mathrm{Co}-\mathrm{N}-\mathrm{C} / \mathrm{MgO}$ catalyst retained its activity for at least four recycling runs. In the fourth cycle, the catalyst gave $84.7 \%$ conversion of furfural and $87.5 \%$ selectivity toward

Table 3

The influence of pressure and temperature on oxidative esterification of furfural to methylfuroate.

\begin{tabular}{lccccc}
\hline Entry & $\begin{array}{c}\text { Pressure } \\
(\mathrm{MPa})\end{array}$ & $\begin{array}{c}\text { Tempera- } \\
\text { ture }\left({ }^{\circ} \mathrm{C}\right)\end{array}$ & $\begin{array}{c}\text { Time } \\
(\mathrm{h})\end{array}$ & $\begin{array}{c}\text { Conversion } \\
(\mathrm{mol} \%)\end{array}$ & $\begin{array}{c}\text { Selectivity } \\
(\mathrm{mol} \%)\end{array}$ \\
\hline 1 & 0.3 & 100 & 6 & 89.0 & 87.3 \\
2 & 0.7 & 100 & 6 & 89.7 & 90.7 \\
3 & 1.0 & 100 & 6 & 89.2 & 90.9 \\
4 & 0.3 & 100 & 1.5 & 53.5 & 89.6 \\
5 & 0.5 & 100 & 1.5 & 54.5 & 91.5 \\
6 & 0.7 & 100 & 1.5 & 49.0 & 91.2 \\
7 & 1.0 & 100 & 1.5 & 51.3 & 89.3 \\
8 & 0.5 & 60 & 6 & 72.5 & 91.5 \\
9 & 0.5 & 80 & 6 & 87.9 & 91.3 \\
10 & 0.5 & 120 & 6 & 91.4 & 90.0 \\
\hline
\end{tabular}

Reaction conditions: $0.5 \mathrm{mmol}$ furfural, $80 \mathrm{mg} \mathrm{Co}-\mathrm{N}-\mathrm{C} / \mathrm{MgO}, 5 \mathrm{~mL}$ methanol.

a Selectivity to methylfuroate. 


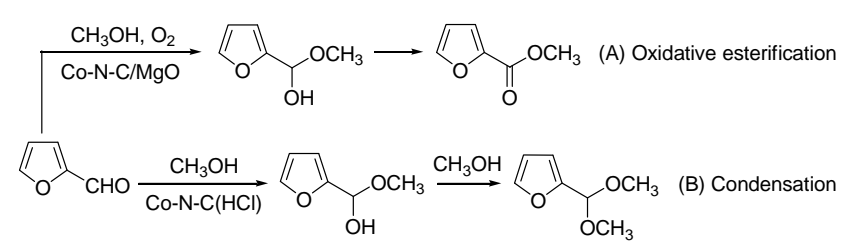

Scheme 1. Oxidative esterification and condensation of furfural with methanol.

methylfuroate. These results show that the Co-N-C/MgO catalyst is stable and can be reused in the oxidation of furfural to methylfuroate.

The oxidative esterification of furfural involves oxidative esterification and condensation of - $\mathrm{CHO}$ with $-\mathrm{OH}$ (Scheme 1). In methanol, furfural is converted into the intermediate hemiacetal, and subsequently undergoes dehydrogenation to form the target product methylfuroate. A competitive reaction of hemiacetal condensation with methanol can occur to generate the side product acetal in the presence of specific catalytic sites or in the blank reaction (without any catalyst or additive). In our case, with $\mathrm{Co}-\mathrm{N}-\mathrm{C} / \mathrm{MgO}$ as the catalyst, the main product was methylfuroate. This suggests that the dehydrogenation of hemiacetal to methylfuroate is dominant. By contrast, with $\mathrm{Co}-\mathrm{N}-\mathrm{C}(\mathrm{HCl})$ as the catalyst, the main reaction was the condensation of $-\mathrm{CHO}$ with $-\mathrm{OH}$ generating the acetal as the main product. To exclude the possibility of producing methylfuroate via esterification of the hydroxyl and carboxyl groups, an oxidative esterification experiment using furancarboxylic acid as the starting substrate was performed in the presence of $\mathrm{Co}-\mathrm{N}-\mathrm{C} / \mathrm{MgO}$ under the same conditions. No methylfuroate was detected in the GC chromatogram (data not shown). This clearly proved that the oxidative esterification did not proceed along the esterification pathway. The details for the mechanism of the $\mathrm{Co}-\mathrm{N}-\mathrm{C} / \mathrm{MgO}$ catalyst are being clarified in further investigations.

\section{Conclusions}

A non-precious metal catalyst of cobalt-nitrogen-doped carbon supported on $\mathrm{MgO}$ was prepared via impregnation and pyrolysis of a cobalt(II) phenanthroline complex on $\mathrm{MgO}$ at 800
${ }^{\circ} \mathrm{C}$ in $\mathrm{N}_{2}$. Investigation of various supports (MgO, activated carbon, $\mathrm{NaX}, \mathrm{NaY}$, and $\mathrm{CaO}$ ) showed the choice of support greatly affected the catalytic activity and selectivity toward the target ester product. The Co- $\mathrm{N}-\mathrm{C} / \mathrm{MgO}$ catalyst exhibited excellent performance for the oxidative esterification of furfural to methylfuroate (93.0\% conversion and $98.5 \%$ selectivity) without the requirement for a basic additive under $0.5 \mathrm{MPa} \mathrm{O}_{2}$ at $100{ }^{\circ} \mathrm{C}$ for $12 \mathrm{~h}$. However, use of $\mathrm{Co}-\mathrm{N}-\mathrm{C}(\mathrm{HCl})$ as the catalyst produced mainly an acetal as a condensation product. Chloride ions had a negative effect on the oxidative esterification. The inclusion of $\mathrm{MgO}$ as a support increases the catalytic efficiency of the cobalt-nitrogen-doped carbon species, and as additive greatly reduces the negative effect of $\mathrm{Cl}^{-}$. Additionally, the oxygen pressure (0.3-1.0 MPa) has a negligible effect on the oxidative esterification of furfural with $\mathrm{Co}-\mathrm{N}-\mathrm{C} / \mathrm{MgO}$. This knowledge could be used to develop non-precious metal catalysts for the oxidative esterification of biomass-derived compounds.

\section{References}

[1] P. Gallezot, Chem. Soc. Rev., 2012, 41, 1538-1558.

[2] Y. Shen, Y. R. Kang, J. K. Sun, C. Wang, B. Wang, F. Xu, R. C. Sun, Chin. J. Catal., 2016, 37, 1362-1368.

[3] X. L. Tong, Y. Ma, Y. D. Li, Appl. Catal. A, 2010, 385, 1-13.

[4] J. Dong, M. M. Zhu, G. S. Zhang, Y. M. Liu, Y. Cao, S. Liu, Y. D. Wang, Chin. J. Catal., 2016, 37, 1669-1675.

[5] M. Besson, P. Gallezot, C. Pinel, Chem. Rev., 2014, 114, 1827-1870.

[6] J. Y. Cai, H. Ma, J. J. Zhang, Z. T. Du, Y. Z. Huang, J. Gao, J. Xu, Chin. J. Catal., 2014, 35, 1653-1660.

[7] X. D. Li, P. Jia, T. F. Wang, ACS Catal., 2016, 6, 7621-7640.

[8] J. P. Lange, E. van der Heide, J. van Buijtenen, R. Price, ChemSusChem, 2012, 5, 150-166.

[9] J. Y. Cai, H. Ma, J. J. Zhang, Q. Song, Z. T. Du, Y. Z. Huang, J. Xu, Chem. Eur. J., 2013, 19, 14215-14223.

[10] M. X. Liu, C. J. Li, Angew. Chem. Int. Ed., 2016, 55, 10806-10810.

[11] E. Taarning, I. S. Nielsen, K. Egeblad, R. Madsen, C. H. Christensen, ChemSusChem, 2008, 1, 75-78.

[12] X. L. Tong, Z. H. Liu, L. H. Yu, Y. D. Li, Chem. Commun., 2015, 51, 3674-3677.

[13] J. Deng, H. J. Song, M. S. Cui, Y. P. Du, Y. Fu, ChemSusChem, 2014, 7, 3334-3340.

[14] R. Bashyam, P. Zelenay, Nature, 2006, 443, 63-66.

[15] G. Wu, K. L. More, C. M. Johnston, P. Zelenay, Science, 2011, 332,

\section{Graphical Abstract}

Chin. J. Catal., 2017, 38: 1148-1154 doi: 10.1016/S1872-2067(17)62841-9

\section{High-efficiency oxidative esterification of furfural to methylfuroate with a non-precious metal Co-N-C/MgO catalyst}

Na Huo, Hong Ma, Xinhong Wang, Tianlong Wang, Gang Wang, Ting Wang, Leilei Hou, Jin Gao *, Jie Xu*

Dalian Polytechnic University;

Dalian Institute of Chemical Physics, Chinese Academy of Sciences

The non-precious metal catalyst Co-N-C/MgO showed high efficiency in the oxidative esterification of furfural to methylfuroate $(93.0 \%$ conversion and $98.5 \%$ selectivity). The reaction with the catalyst $\mathrm{Co}-\mathrm{N}-\mathrm{C}(\mathrm{HCl})$ proceeded via a condensation pathway with acetal as the dominant product.

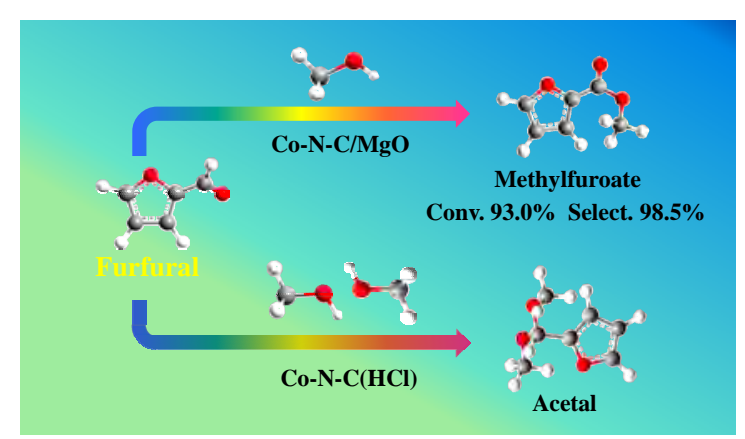


443-447.

[16] D. H. Deng, L. Yu, X. Q. Chen, G. X. Wang, L. Jin, X. L. Pan, J. Deng, G. Q. Sun, X. H. Bao, Angew. Chem. Int. Ed., 2013, 52, 371-375.

[17] R. V. Jagadeesh, H. Junge, M. Beller, ChemSusChem, 2015, 8, 92-96.

[18] F. A. Westerhaus, R. V. Jagadeesh, G. Wienhofer, M. M. Pohl, J. Radnik, A. E. Surkus, J. Rabeah, K. Junge, H. Junge, M. Nielsen, A. Bruckner, M. Beller, Nat. Chem., 2013, 5, 537-543.

[19] D. Banerjee, K. Junge, M. Beller, Angew. Chem. Int. Ed., 2014, 53, 13049-13053.

[20] R. V. Jagadeesh, H. Junge, M. Beller, Nat. Commun., 2014, 5, 4123.

[21] L. L. Zhang, A. Q. Wang, W. T. Wang, Y. Q. Huang, X. Y. Liu, S. Miao, J. Y. Liu, T. Zhang, ACS Catal, 2015, 5, 6563-6572.

[22] W. G. Liu, L. L. Zhang, W. S. Yan, X. Y. Liu, X. F. Yang, S. Miao, W. T. Wang, A. Q. Wang, T. Zhang, Chem. Sci., 2016, 7, 5758-5764.
[23] H. Ma, X. Nie, J. Y. Cai, C. Chen, J. Gao, H. Miao, J. Xu, Sci. China Chem., 2010, 53, 1497-1501.

[24] Y. X. Sun, H. Ma, X. Q. Jia, J. P. Ma, Y. Luo, J. Gao, J. Xu, ChemCatChem, 2016, 8, 2907-2911.

[25] R. V. Jagadeesh, A. E. Surkus, H. Junge, M. M. Pohl, J. Radnik, J. Rabeah, H. M. Huan, V. Schunemann, A. Bruckner, M. Beller, Science, 2013, 342, 1073-1076.

[26] R. V. Jagadeesh, H. Junge, M. M. Pohl, J. Radnik, A. Bruckner, M. Beller, J. Am. Chem. Soc., 2013, 135, 10776-10782.

[27] H. W. Liang, W. Wei, Z. S. Wu, X. L. Feng, K. Mullen, J. Am. Chem. Soc., 2013, 135, 16002-16005.

[28] G. Wu, P. Zelenay, Acc. Chem. Res., 2013, 46, 1878-1889.

[29] J. Masa, W. Xia, M. Muhler, W. Schuhmann, Angew. Chem. Int. Ed., 2015, 54, 10102-10120.

\title{
非贵金属Co-N-C/MgO高效催化糠醛氧化酯化制糠酸甲酯
}

\author{
霍 娜 ${ }^{\mathrm{a}, \mathrm{b}}$, 马 红 ${ }^{\mathrm{b}}$, 王新红 ${ }^{\mathrm{a}}$, 王天龙 ${ }^{\mathrm{a}, \mathrm{b}}$, 王 刚 ${ }^{\mathrm{a}, \mathrm{b}}$, 王 婷, ${ }^{\mathrm{a}, \mathrm{b}}$, 候磊磊, 高 进 ${ }^{\mathrm{b}, \#}$, 徐 杰, \\ a 大连工业大学纺织与材料工程学院, 辽宁大连 116034 \\ $\mathrm{b}$ 中国科学院大连化学物理研究所催化基础国家重点实验室, 洁净能源国家实验室(筹), 辽宁大连116023
}

摘要: 设计开发绿色、可持续的生物质资源高效转化制化学品催化过程具有重要的科学与应用研究价值. 生物质基平台分 子糠醛在分子氧存在下与甲醇发生氧化酯化, 提供了一条糠酸甲酯的“非石油基”合成新路线. 该反应采用贵金属/非贵金 属催化体系, 目前通常需要引入 $\mathrm{K}_{2} \mathrm{CO}_{3}$ 或 $\mathrm{CH}_{3} \mathrm{ONa}$ 等碱性添加剂, 以提高催化氧化酯化反应活性和选择性; 但是存在活性组 分流失、生成副产物及污染环境等问题, 阻碍了其进一步应用. 探索高性能非贵金属催化剂, 实现无碱条件下糠醛高效氧 化酯化, 对于提高该生物质路线竞争力与推动工业化进程具有重要意义.

本文利用浸渍法将 1,10 -邻菲罗啉合钴(II)负载到碱性载体氧化镁上, 在氮气气氛下 $800{ }^{\circ} \mathrm{C}$ 热解, 制备了非贵金属 Co-N-C/MgO催化剂. 在糠醛氧化酯化制糠酸甲酯反应中, $\mathrm{Co}-\mathrm{N}-\mathrm{C} / \mathrm{MgO}$ 催化剂表现出优异的性能, 在 $0.5 \mathrm{MPa} \mathrm{O}_{2}, 100{ }^{\circ} \mathrm{C}$ 条 件下反应 $12 \mathrm{~h}$, 糠醛转化率达到 $93.0 \%$, 糠酸甲酯选择性达到 $98.5 \%$, 远超过相同方法制备的其他载体(活性炭、NaX、NaY和 $\mathrm{CaO}$ )负载的钴基催化剂, 实现了无碱性添加剂条件下糠醛高效氧化酯化制糠酸甲酯. X射线光电子能谱、X射线衍射、透 射电镜、元素分析以及对比实验结果表明, Co-N-C/MgO催化剂上可能存在含钴的氮掺杂碳物种; 该催化剂在糠醛氧化酯 化中的高性能与其脱氢能力密切相关. 并且在 $0.3-1.0 \mathrm{MPa}$ 氧气压力范围内, $\mathrm{Co}-\mathrm{N}-\mathrm{C} / \mathrm{MgO}$ 催化糠醛氧化酯化过程基本不受 压力变化影响.

糠酫与甲醇的氧化酯化反应和缩合反应为两个竞争路径, 反应路径决定了反应的主要产物. 我们使用盐酸处理 Co-N-C/MgO催化剂, 脱除MgO载体, 制备了 $\mathrm{Co}-\mathrm{N}-\mathrm{C}(\mathrm{HCl})$ 催化剂. 当使用该催化剂时, 糠醛与甲醇主要发生缩合反应, 得到 缩醛产物2-(二甲氧基甲基)呋喃. 如果在 $\mathrm{Co}-\mathrm{N}-\mathrm{C}(\mathrm{HCl})$ 催化反应体系中引入 $\mathrm{MgO}$ 添加剂, 则主要发生糠醛氧化酯化反应, 主 产物为糠酸甲酯. 为了验证 $\mathrm{Cl}^{-}$是否对反应产生影响, 使用 $\mathrm{NaCl}$ 溶液对 $\mathrm{Co}-\mathrm{N}-\mathrm{C} / \mathrm{MgO}$ 进行浸渍、清洗处理, 或直接使用 $\mathrm{NaCl}$ 为添加剂; 在这两种情况下, 糠醛转化率与糠酸甲酯选择性均下降, 表明 $\mathrm{Cl}^{-}$对糠醛氧化酯化反应具有负面作用. 根据实验 结果, 阴离子 $\left(\mathrm{Cl}^{-}\right)$可能与 $\mathrm{Co}(\mathrm{II})$ 中心发生配位, 从而影响了金属活性中心的催化性能. $\mathrm{Co}-\mathrm{N}-\mathrm{C}(\mathrm{HCl})$ 加入氧化镁, 使得糠醛 主要遵循氧化酯化路径进行转化, 降低 $\mathrm{Cl}^{-}$对 $\mathrm{Co}-\mathrm{N}-\mathrm{C}(\mathrm{HCl})$ 催化活性中心的影响. 以上研究可为生物质基醛类化合物氧化酯 化转化过程以及高性能非贵金属催化剂的设计开发提供有益参考.

关键词: 催化; 钴-氮-碳; 糠醛; 糠酸甲酯; 氧化镁; 氧化酯化

收稿日期: 2017-03-07. 接受日期: 2017-04-15. 出版日期: 2017-07-05.

*通讯联系人. 电话/传真: (0411)84379245; 电子信箱: xujie@dicp.ac.cn

\#通讯联系人. 电话/传真: (0411)84379245; 电子信箱: gaojin@dicp.ac.cn

基金来源：国家自然科学基金(21233008, 21643013, 21690084); 中国科学院重点战略研究项目(XDB17020300); 中国科学院青年 创新促进会(2013121).

本文的英文电子版由Elsevier出版社在ScienceDirect上出版(http://www.sciencedirect.com/science/journal/18722067). 